\title{
DETECTION OF TUBERCULOSIS IN PLWHA- A STUDY OF YIELD BY MICROSCOPY AND CBNAAT WITH CD4 CORRELATION
}

\author{
Natesan Karthirvel Senthilnathan', Sappani Kasipandian², Kavungal Smitha Chandran ${ }^{3}$
}

\author{
${ }^{1}$ Associate Professor and HOD, Department of General Medicine, KAP Vishwanathan Government Medical College, Tiruchirappalli, \\ Tamilnadu, India. \\ ${ }^{2}$ Associate Professor, Department of General Medicine, Velammal Medical College and Research Institute, Anuppanadi, Madurai, \\ Tamilnadu, India. \\ ${ }^{3}$ Postgraduate Student, Department of Neurology, Madras Medical College, Chennai, Tamilnadu, India. \\ ABSTRACT
}

\section{BACKGROUND}

Tuberculosis (TB) related deaths are rising in the world and in 2013 the mortality was reported as 36 million deaths in Patients Living with HIV and AIDS (PLWHA), because of lack of proper diagnosis at the apt time. So an urgent need to implement newer diagnostic modalities with the Light Emitting Diode Fluorescent Microscopy (LED-FM) ${ }^{1}$ and Cartridge Based Nucleic Acid Amplification Test (CBNAAT) for the detection of MTB, especially in highly HIV prevalent areas. ${ }^{2}$ In this study, we are analysing by the above two methods in the detection of AFB in Ziehl-Neelsen (ZN) Smear -ve suspected Pulmonary TB (PTB), MTB in Extrapulmonary TB (EPTB) in PLWHA, CD4 count correlation by CBNAAT and LED-FM and identify Rifampicin Resistance by CBNAAT in HIV +ve patients.

Aims and Objectives-

1. To compare the detection of AFB by CBNAAT and LED-FM in ZN Smear -ve suspected PTB and MTP in EPTB of PLWHA.

2. To compare the CD4 count correlation by CBNAAT and LED-FM and to identify Rifampicin Resistance by CBNAAT in HIV +ve patients.

\section{MATERIALS AND METHODS}

This descriptive study was conducted in MGM Govt. Tertiary Care Hospital attached to KAPV Govt. Medical College, Trichy from January 2015 to April 2016. Totally, 130 PLWHA who were attending the Medical OPD, Chest Medicine OPD, STD Clinic and ART Centre with signs and symptoms of PTB and EPTB were selected. All the patients were subjected to chest x-ray, ZN smear examination, pleural fluid analyses, Fine Needle Aspiration Cytology (FNAC) of lymph node for the detection of MTP in PLWHA, CD4 count correlation and Rifampicin Resistance in HIV +ve patients by these methods.

\section{RESULTS}

In this study of 130 patients, HIV was +ve in 65 and HIV was -ve in 65, of which ZN smear -ve suspected PTB was 80 and EPTB was 50 patients. Of the 80 PLWHA of ZN smear -ve suspected PTB, CBNAAT was +ve in $49(61.25 \%)$ and CBNAAT was -ve in 31 (38.75\%) and LED-FM was +ve in 17 (21.25\%) and LED-FM was -ve in 63 (78.75\%). Of the 30 PLWHA's, FNAC specimens of TB Lymphadenitis LED-FM was +ve in $12(40 \%)$ and was -ve in $18(60 \%)$ and CBNAAT was +ve in $20(66.66 \%)$ and was -ve in 10 (33.33\%). Of the 20 PLWHA of suspected TB pleural effusion, CBNAAT was +ve in 5 (25\%) and was -ve in 15 (75\%) and LED-FM was +ve in $3(15 \%)$ and was -ve in 17 (85\%). Of the 65 HIV +ve, CBNAAT was +ve in $34(52.3 \%)$ more than LED-FM +ve in 14 (21.3\%) based on CD4 count levels. More MTP was detected by both CBNAAT vs. LED-FM (28 vs. 10) with CD4 count of $100-350$ cells/ $\mu \mathrm{L}$ and next with CD4 count < 100 cells/ $\mu \mathrm{L} 19$ vs. 6. Of the 49 (61.3\%) CBNAAT +ve of 80 PLWHA Rifampicin Resistance was found only in $3(6.12 \%)$ patients.

\section{CONCLUSION}

In this study of the 130 PLWHA, CBNAAT + ve was higher than LED-FM +ve in the 80 ZN smear -ve suspected PTB, 30 TB lymphadenitis and 20 TB pleural effusion samples, i.e. $49(61.25 \%)>17(21.25 \%), 20(66.66 \%)>12(40 \%), 5(25 \%)>3(15 \%)$ respectively in the ratio of 2.88, 1.66, 1.66 times in CBNAAT +ve vs. LED-FM +ve. Of the 65 HIV +ve cases, CBNAAT was +ve in 34 (52.3\%) than LED-FM +ve in 14 (21.3\%) cases based on CD4 counts. Both CBNAAT +ve and LED-FM +ve were high with CD4 count $<350$ cells/ mL and less with CD4 count > 350 cells/mL. Of the 49 (61.3\%) CBNAAT +ve ZN smear -ve suspected PTB of PLWHA Rifampicin Resistance was found only in 3 (6.12\%).

\section{KEY WORDS}

PLWHA, CBNAAT, PTB, EPTB, LED-FM.

HOW TO CITE THIS ARTICLE: Senthilnathan NK, Kasipandian S, Chandran KS. Detection of tuberculosis in PLWHA- a study of yield by microscopy and CBNAAT with CD4 correlation. J. Evolution Med. Dent. Sci. 2018;7(38):4182-4187, DOI: $10.14260 /$ jemds/2018/935

'Financial or Other Competing Interest': None.

Submission 27-08-2018, Peer Review 05-09-2018,

Acceptance 11-09-2018, Published 17-09-2018.

Corresponding Author:

Dr. Sappani Kasipandian,

Devi Illam, No. 3/423/5, Meenakshi Amman Street,

Opp. To Pandi Kovil, Pandian Nagar, Madurai-20, Tamilnadu, India

E-mail: sankarkasipandian@yahoo.com

DOI: $10.14260 /$ jemds $/ 2018 / 935$

\section{(c) (i) $९$}

\section{BACKGROUND}

TB most commonly affects the lungs in two-thirds of the patients and involves almost all the organ systems in the body and other than lungs are involved in one-third of the patients. The public health importance of TB is that when it is drug susceptible and treated properly it is curable in majority of patients and if left untreated fatal in $50-60 \%$ of patients within 5 years. $^{3}$ In 2013, 5.7 million new TB cases were reported to WHO of which $95 \%$ was from the developing 
countries and around two-thirds of total new cases were underdiagnosed because of poor resources in detection as well as socioeconomic cultural reasons. Of this newly diagnosed TB cases $28 \%$ were drug resistant, $13 \%$ were HIV associated and the mortality was also high in these groups. A total of 0.36 million patients died every year because of TB, about $28 \%$ of the total cases of TB were drug resistant, especially to Rifampicin and INH.

In India, prevalence is about $10 \%$ with HIV and active TB. Untreated TB will accelerate the course of HIV infection in contrast to infection with atypical mycobacteria, the active TB develops early in the course of HIV infection and can be considered as an early clinical sign of HIV disease. Evolution of active TB is faster in HIV patients, i.e. few weeks as opposed to months to years in general population. Sputum smears are less frequently positive among HIV-TB coinfections, so that there is a diagnostic challenge for these patients.

Incidence of EPTB is higher in PLWHA than the normal population, constituting about $40-60 \%$ of the cases. ${ }^{3}$ EPTB mostly manifests in lymph nodes, pleural involvement, genital and urinary tract, joints and bones, meninges, peritoneum and pericardium. TB lymphadenitis in PLWHA manifests as painless matted nodes, mostly in posterior cervical region have less organised granulomas, so more chance of detection by microscopy and culture. Pleural TB ( $20 \%$ of patients) mostly due to hypersensitivity reactions to the microbial antigens or sometimes contiguous spread. The mechanisms responsible for cellular depletion, dysfunction of CD4 T-cells is due to direct infection and destruction by the virus and indirect effects like immune clearance, cell death associated with abnormal immune activation, immune exhaustion etc.

\section{Radiological Diagnosis}

The initial suspicion of PTB is based on chest x-ray PA view. The classic picture is upper lobe disease with pulmonary infiltrates and cavities, but any radiographic pattern may be seen, that is from normal film or solitary nodule or diffuse infiltrates. In HIV-TB co-infection, culture +ve or AFB +ve, the chest $\mathrm{x}$-ray findings are not seen as the classical picture, may be normal on chest $\mathrm{x}$-ray, more when the immunity is low. CT Chest, HRCT is helpful with doubtful $\mathrm{x}$-rays.

Immune Reconstitution Inflammatory Syndrome (IRIS), occurs in the HIV-TB co-infected patients if we are starting ART first because of undiagnosed TB. When effective ART is implemented, cell-mediated immunity of the patient improves and there is a large cytokine release to the tubercle bacilli which will cause flare-up of symptoms and signs like lymphadenopathy, respiratory symptoms or chest x-ray manifestations. Lower baseline CD4 count and earlier starting of ART are the main risk factors. To prevent IRIS, we prefer newer methods with higher diagnostic yield (CBNAAT, LED$\mathrm{FM}$ ) to detect $\mathrm{TB}$ in HIV rather than the conventional methods.

\section{LED-Fluorescent Microscopy (LED-FM)}

In traditional light microscopy using $\mathrm{ZN}$ technique, each smear examination may take an average of $5-10$ minutes. These put high workloads for laboratories and may consequently result in decreased reliability. LED-FM is $10 \%$ more sensitive than ZN smear microscopy. Fluorescent AFB can be seen at lower magnification, can be examined in lesser time and reduce the laboratory workloads of $25 \%$. It is relatively cheaper, inexpensive, have an effective lifespan of thousands of hours, ${ }^{4}$ can work even with power supply from batteries and more suitable for resource poor countries. It has higher sensitivity, but lower specificity than ZN smear microscopy.

\section{GeneXpert MTB/RIF Assay is a Cartridge Based Nucleic Acid Amplification Technique (CBNAAT) ${ }^{3}$}

It is an automated rapid diagnostic test based on the amplification of nucleic acids of the MTB, can identify MTB DNA and resistance to Rifampicin (RIF) within 1 - 2 hours, less time consuming with minimal biosafety and training requirements for operation. ${ }^{5}$ It has high sensitivity $98 \%$ in AFB +ve, 70\% in AFV -ve and high specificity 99\% for detection of AFB even as small as 131 colony forming units (cfu) per mL compared to about 10,000 cfu with conventional smear microscopy. ${ }^{6}$ CBNAAT can even be set up easily in a simple laboratory without much technical requirements. But its cost effectiveness and maintenance charges are relatively higher. The WHO endorsed to use the CBNAAT as the initial diagnostic test in suspected MDR-TB in adults and paediatrics, HIV-associated TB and TB endemic countries in December 2012.7

In India, CBNAAT was adopted by RNTCP in 2012 and started as a pilot project in Maharashtra state. Now it is currently available at more centres and the aim is to establish a link with all the hospitals to a medical college and also implemented in private setup. In our KAPV Govt. Medical College, Trichy, Tamilnadu, it started functioning since 2015 January.

\section{Aims and Objectives}

1. To compare the detection of AFB by CBNAAT and LEDFM in ZN Smear -ve suspected PTB and MTP in EPTB of PLWHA.

2. To compare the CD4 count correlation by CBNAAT and LED-FM and to identify Rifampicin Resistance by CBNAAT in HIV +ve patients.

\section{MATERIALS AND METHODS Study Population}

This study was conducted in Mahatma Gandhi Memorial Govt. Tertiary Care Hospital attached to KAPV Govt. Medical College, Tiruchirapalli, Tamilnadu, India. Totally, 130 PLWHA with suspected TB, EPTB who were attending the General Medicine OPD, Chest Medicine OPD, STD Clinic and ART Centre with pulmonary symptoms of cough for more than one week, loss of weight and loss of appetite and night sweats, lymphadenopathy etc. were subjected to Chest x-ray PA view, FNAC, pleural fluid analyses, sputum analyses for the detection of MTP in PLWHA, CD4 count, Correlation and Rifampicin Resistance in HIV +ve patients by these methods.

\section{Consent}

Prior written consent was obtained from all the patients included in this study in their own mother tongue.

\section{Study Design}

Descriptive study. 
Sample Size- Sample size was taken as per our convenience.

\section{Study Period and Duration}

From January 2015 to April 2016 - 16 months.

\section{Ethical Committee Approval}

This study was approved by the Ethical Committee of the KAPV Govt. Medical College, Trichy, Institutional Review Board.

\section{Inclusion Criteria}

1. PLWHA suspected PTB with ZN smear AFB negative, chest $\mathrm{X}$-ray positive findings.

2. PLWHA suspected with TB lymphadenitis, TB pleural effusion with ZN smear AFB negative.

\section{Exclusion Criteria}

Patients with past history of TB, already on ATT.

\section{Statistical Analysis}

The information collected regarding all cases were tabulated in a Master Chart. Statistical analysis was performed using SPSS software version 16. 'P' value calculated from Chisquare test was used for consolidated data. P value $<0.05$ was taken as significant.

\section{RESULTS}

In this study, 130 PLWHA were included of this HIV +ve in 65 and -ve in 65 patients. Suspected PTB in 80 and ЕРTB in 50, of the 50 EPTB suspected TB pleural effusion in 20 and TB lymphadenitis in 30 patients.

The samples were examined for AFB and MTB by CBNAAT and LED-FM and the results were given as CBNAAT +ve, -ve and LED-FM +ve and -ve. CD4 count of all the 65 HIV +ve patients were noted and analysed for any correlation with these results. In each group Age, Sex, BMI, AFT and MTB status were analysed for any correlation between HIV +ve and -ve patients.

\section{Age Distribution}

Both HIV +ve and HIV -ve patients were categorised as six groups and they were graphically represented $<20$ years, 21 -
30, 31-40, 41-50, 51-60 and $>61$ years. Suspected PTB based on chest $\mathrm{x}$-ray and clinical findings were more common in younger age group when compared to HIV -ve patients than HIV +ve.

\section{Sex Distribution}

Of the 40 HIV +ve ZN smear -ve suspected PTB of 25 (62.5\%) patients were males, 15 (37.5\%) were females and of the 40 HIV -ve ZN smear -ve suspected PTB 27 (67.5\%) were males and $13(32.5 \%)$ were females. HIV +ve were more $(37.5 \%)$ in the age group of 41 - 50 years and next $25 \%$ was in the age group of 31 - 40 years and in HIV -ve it was (27.5\%) in the age group below 20 years and next $(22.5 \%)$ in the age group of 31 - 40 years.

\section{BMI Distribution}

In this study mean BMI was 19 and among the 40 HIV +ve, $\mathrm{BMI}<19$ were $28(70 \%)$ and $\mathrm{BMI}>19$ were $12(30 \%)$. Among the 40 HIV -ve, BMI < 19 were $13(32.5 \%)$ and $\mathrm{BMI}>$ 19 were 27 (67.5\%). Patients with suspected PTB in HIV -ve individuals have higher mean BMI and SD than HIV +ve 20.95, 1.54 vs. $18.39,2.35$ which was statistically significant $\mathrm{X}^{2}=11.257, \mathrm{Df}=1.001<0.05$ analysed using Chi-square testing SPSS software.

Comparison of detection of AFB in ZN smear -ve suspected PTB of PLWHA by LED-FM and CBNAAT

Of the $40 \mathrm{HIV}$ +ve patients, LED-FM was -ve in 32 (80\%) and +ve in $8(20 \%)$ and CBNAAT was -ve in $19(47.5 \%)$ and CBNAAT was +ve in $21(52.5 \%)$ patients. Of the $40 \mathrm{HIV}-\mathrm{ve}$ patients, LED-FM was -ve in 31 (77.5\%) and LED-FM was +ve in $9(22.5 \%)$ and CBNAAT was -ve in $12(30 \%)$ and CBNAAT was +ve in $28(70 \%)$ patients. LED-FM positivity and CBNAAT positivity were high in HIV -ve $31(77.5 \%)$ and 28 (70\%) than HIV +ve $8(20 \%)$ and 21 (52.5\%). Increased CBNAAT +ve in HIV -ve 28 (70\%) than in HIV +ve 21 (52.5), which was statistically not significant. Totally, of the $80 \mathrm{ZN}$ smear -ve suspected PTB patients more number of AFB was detected by CBNAAT $49(61.25 \%)$ than by LED-FM 17 (21.25\%).

\begin{tabular}{|c|c|c|c|c|c|c|c|c|c|c|c|c|c|}
\hline \multirow{3}{*}{ HIV Status } & \multicolumn{6}{|c|}{ LED-FM } & \multicolumn{6}{|c|}{ CBNAAT Result } & \multirow{3}{*}{ Statistical Inference } \\
\hline & \multicolumn{2}{|c|}{ Negative } & \multicolumn{2}{|c|}{ Positive } & \multicolumn{2}{|c|}{ Total } & \multicolumn{2}{|c|}{ Negative } & \multicolumn{2}{|c|}{ Positive } & \multicolumn{2}{|c|}{ Total } & \\
\hline & $\mathbf{n}$ & $\%$ & $\mathbf{n}$ & $\%$ & $\mathbf{n}$ & $\%$ & $\mathbf{n}$ & $\%$ & $\mathbf{n}$ & $\%$ & $\mathbf{n}$ & $\%$ & \\
\hline HIV -ve & 31 & 77.5 & 9 & 22.5 & 40 & 100 & 12 & 30 & 28 & 70 & 40 & 100 & $\begin{array}{c}\mathrm{X}^{2}=16.29 \mathrm{df}=1 \\
0.001<0.05 \\
\text { Highly Significant }\end{array}$ \\
\hline HIV +ve & 32 & 80 & 8 & 20 & 40 & 100 & 19 & 47.5 & 21 & 52.5 & 40 & 100 & $\begin{array}{c}\mathrm{X}^{2}=7.79 \mathrm{df}=1 \\
0.005<0.05 \\
\text { Significant }\end{array}$ \\
\hline
\end{tabular}




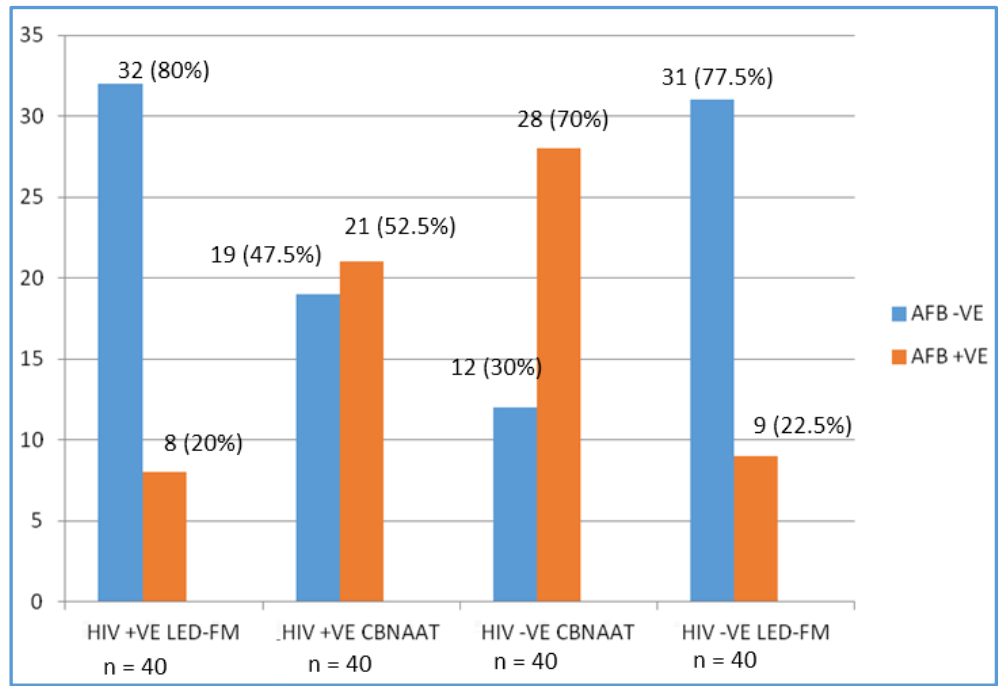

Chart 1. Comparison of AFB detection by LED-FM and CBNAAT in suspected PTB of ZN smear -ve based on HIV Status

Detection of Rifampicin Resistance with CBNAAT

Of the $49(61.3 \%)$ CBNAAT +ve of 80 PLWHA, Rifampicin resistance was found only in $3(6.12 \%)$ patients.

\begin{tabular}{|c|c|c|c|c|c|c|}
\hline \multirow{2}{*}{ Rifampicin Resistance } & \multicolumn{2}{|c|}{ HIV +ve HIV -ve } & \multicolumn{2}{c|}{ Total } \\
\cline { 2 - 7 } & $\mathbf{n}$ & $\mathbf{\%}$ & $\mathbf{n}$ & $\mathbf{\%}$ & $\mathbf{n}$ & $\mathbf{\%}$ \\
\hline Detected & 1 & $4.76 \%$ & 2 & $7.14 \%$ & 3 & $6.12 \%$ \\
\hline Not Detected & 20 & $95.23 \%$ & 26 & $92.85 \%$ & 46 & $93.88 \%$ \\
\hline Total & $\mathbf{2 1}$ & $\mathbf{1 0 0 . 0} \%$ & $\mathbf{2 8}$ & $\mathbf{1 0 0 . 0} \%$ & $\mathbf{4 9}$ & $\mathbf{1 0 0 . 0} \%$ \\
\hline Table 2. Detection of Rifampicin Resistance of PTB with CBNAAT based on HIV Status \\
\hline
\end{tabular}

Comparison of detection of MTB in FNAC specimens of suspected TB Lymphadenitis by CBNAAT and LED-FM based on HIV

\section{Status}

In this study of the 15 HIV +ve patients, LED-FM was +ve in 13 (86.66\%) and was -ve in 2 (13.33\%). But CBNAAT was +ve in all 15 $(100 \%)$ HIV +ve patients and no CBNAAT was -ve. Of the 15 HIV -ve patients LED-FM was -ve in all the 15 (100\%) patients, but no LED-FM +ve findings. But CBNAAT was +ve in 7 (46.66\%) and was -ve in 8 (53.33\%). So CBNAAT 22 (73.3\%) had better detection of MTB than by LED-FM 13 (43.3\%) out of 30 patients, which was not significant statistically.

\begin{tabular}{|c|c|c|c|c|c|c|c|c|c|c|c|c|c|}
\hline \multirow{3}{*}{ HIV Status } & \multicolumn{6}{|c|}{ LED-FM } & \multicolumn{6}{|c|}{ CBNAAT } & \multirow{3}{*}{ Statistical Inference } \\
\hline & \multicolumn{2}{|c|}{ Negative } & \multicolumn{2}{|c|}{ Positive } & \multicolumn{2}{|c|}{ Total } & \multicolumn{2}{|c|}{ Negative } & \multicolumn{2}{|c|}{ Positive } & \multicolumn{2}{|c|}{ Total } & \\
\hline & $\mathrm{n}$ & $\%$ & $\mathrm{n}$ & $\%$ & $\mathrm{n}$ & $\%$ & $\mathrm{n}$ & $\%$ & $\mathbf{n}$ & $\%$ & $\mathbf{n}$ & $\%$ & \\
\hline HIV -ve & 15 & 100 & 0 & 0 & 15 & 100 & 8 & 53.33 & 7 & 46.66 & 15 & 100 & $\begin{array}{c}\mathrm{X}^{2}=6.71 \mathrm{df}=1.010<0.05 \\
\text { Significant }\end{array}$ \\
\hline HIV +ve & 2 & 13.33 & 13 & 86.66 & 15 & 100 & 0 & 0 & 15 & 100 & 15 & 100 & $\begin{array}{c}\mathrm{X}^{2}=0.536 \mathrm{df}=1.464>0.05 \\
\text { Not Significant }\end{array}$ \\
\hline
\end{tabular}

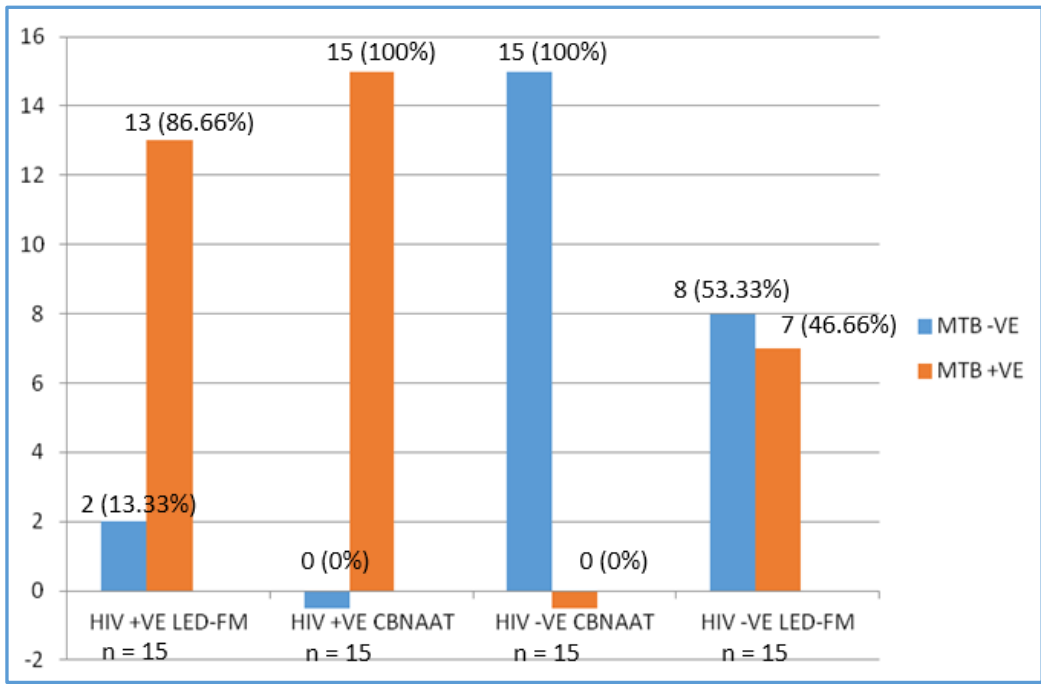

Chart 2. Comparison of MTB detection by LED-FM and CBNAAT in suspected TB Lymphadenitis based on HIV Status 
Detection of MTB in suspected TB Pleural Effusion by CBNAAT and LED-FM

In this study of the $10 \mathrm{HIV}+\mathrm{ve}$, suspected TB pleural effusion CBNAAT was +ve in $2(20 \%)$ and was -ve in 8 (80\%) patients and LED-FM was +ve in $1(10 \%)$ and was -ve in $9(90 \%)$ patients. Of the 10 HIV -ve, CBNAAT was +ve in 3 (30\%) and CBNAAT was -ve in 7 (70\%), and all 10 (100\%) HIV -ve were LED-FM -ve. No LED-FM was +ve. Compared to LED-FM 1 (5\%), CBNAAT detect more MTB 5 (25\%) out of 20 PLWHA of suspected TB pleural effusion.

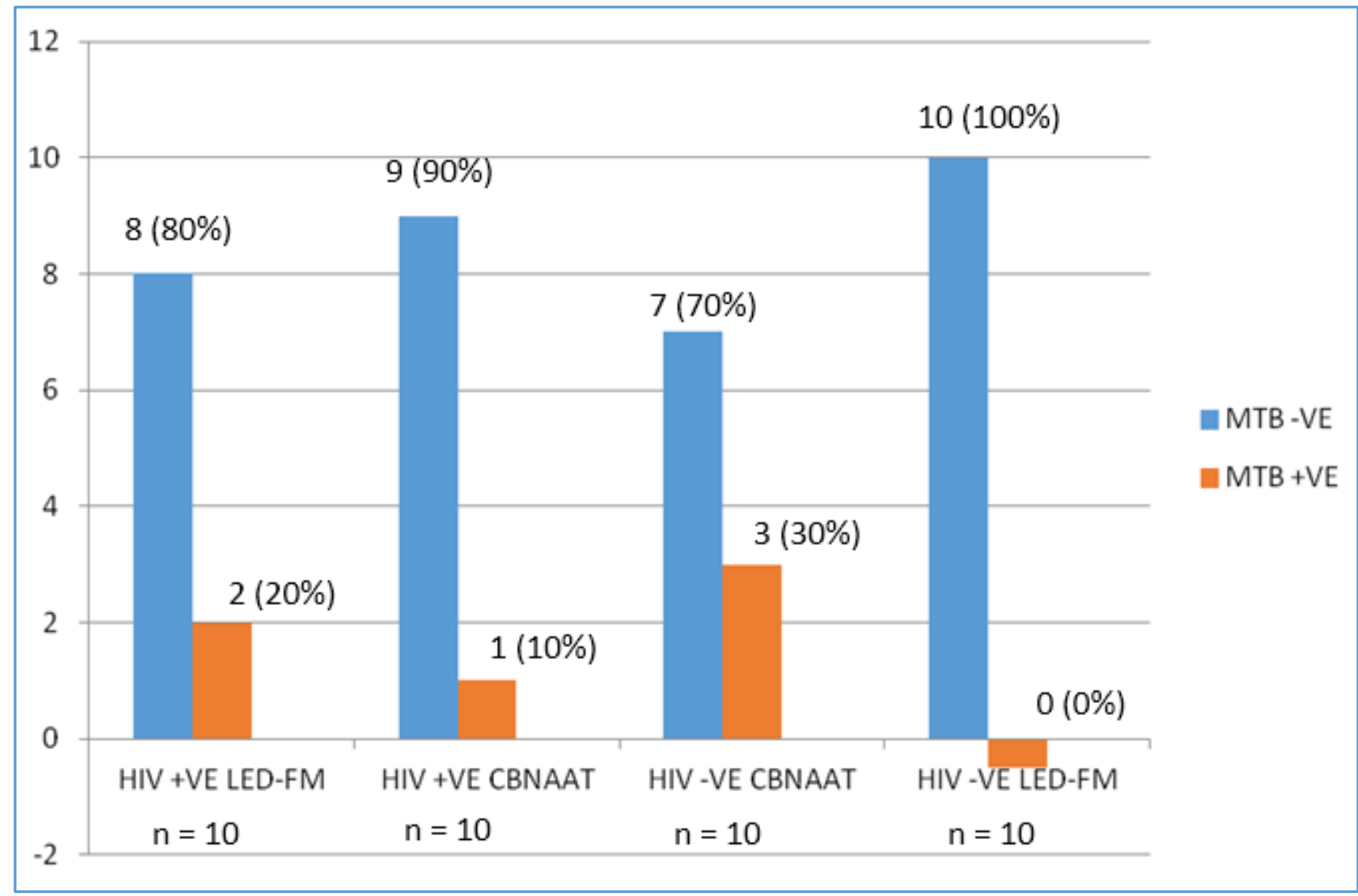

Chart 3. Comparison of MTB detection by LED-FM and CBNAAT in suspected TB Pleural Effusion based on HIV Status

\begin{tabular}{|c|c|c|c|c|c|c|c|c|c|c|c|c|c|c|c|}
\hline \multirow[b]{2}{*}{$\begin{array}{c}\text { HIV } \\
\text { Status }\end{array}$} & \multirow[b]{2}{*}{$\mathbf{n}$} & \multirow[b]{2}{*}{$\%$} & \multicolumn{6}{|c|}{ CBNAAT } & \multicolumn{6}{|c|}{ LED-FM } & \\
\hline & & & $\begin{array}{c}\text { MTB } \\
\text { Status } \\
\end{array}$ & $\mathbf{n}$ & $\%$ & \begin{tabular}{|c|} 
MTB \\
Status \\
\end{tabular} & $\mathbf{n}$ & $\%$ & $\begin{array}{c}\text { MTB } \\
\text { Status } \\
\end{array}$ & $\mathbf{n}$ & $\%$ & $\begin{array}{c}\text { MTB } \\
\text { Status } \\
\end{array}$ & $\mathbf{n}$ & $\%$ & \\
\hline HIV +ve & 15 & 50 & $\mathrm{MTB}+\mathrm{VE}$ & 15 & 100 & $\begin{array}{l}\text { MTB } \\
\text {-VE }\end{array}$ & 0 & 0 & $\begin{array}{l}\text { MTB } \\
+ \text { VE }\end{array}$ & 13 & 86.7 & $\begin{array}{c}\text { MTB } \\
\text {-VE }\end{array}$ & 2 & 13.3 & $\begin{array}{c}\mathrm{X}^{2}=0.536 \\
.464>0.05 \\
\text { Not Significant } \\
\end{array}$ \\
\hline HIV -ve & 15 & 50 & $\mathrm{MTB}+\mathrm{VE}$ & 7 & 46.7 & $\begin{array}{l}\text { MTB } \\
-V E\end{array}$ & 8 & 53.3 & $\begin{array}{l}\text { MTB } \\
+\mathrm{VE}\end{array}$ & 0 & 0 & $\begin{array}{c}\text { MTB } \\
-V E\end{array}$ & 15 & 100 & $\begin{array}{c}\mathrm{X}^{2}=3.75 \\
.043<0.05 \\
\text { Significant }\end{array}$ \\
\hline
\end{tabular}

Table 4. Comparison of MTB detection by LED-FM and CBNAAT in suspected TB Pleural Effusion based on HIV Status

\begin{tabular}{|c|c|c|c|c|c|c|c|c|c|c|c|}
\hline \multirow[t]{2}{*}{ CD4 Count } & \multicolumn{2}{|c|}{ Total } & \multicolumn{4}{|c|}{ CBNAAT } & \multicolumn{4}{|c|}{ LED-FM } & \multirow[t]{2}{*}{$\begin{array}{l}\text { Statistical } \\
\text { Inference }\end{array}$} \\
\hline & $\mathbf{n}$ & $\%$ & +ve & $\%$ & -ve & $\%$ & +ve & $\%$ & -ve & $\%$ & \\
\hline Below 100 & 14 & 21.5 & 9 & 13.8 & 5 & 7.69 & 4 & 6.15 & 10 & 15.38 & 0.130 Not Sig \\
\hline 101 to 350 & 40 & 61.5 & 19 & 29.2 & 21 & 32.3 & 6 & 9.23 & 34 & 52.30 & 0.004 Sig. \\
\hline 351 to 500 & 5 & 7.7 & 2 & 3.07 & 3 & 4.61 & 1 & 1.53 & 4 & 6.15 & 1.0 Not Sig. \\
\hline $\begin{array}{c}500 \text { and } \\
\text { Above }\end{array}$ & 6 & 9.2 & 4 & 6.15 & 2 & 3.07 & 3 & 4.61 & 3 & 4.61 & 1.0 Not Sig. \\
\hline Total & 65 & 100 & 34 & 52.3 & 31 & 47.67 & 14 & 21.52 & 51 & 78.44 & \\
\hline
\end{tabular}

Of the 65 HIV +ve patients, CBNAAT was +ve in 34 (52.5\%) more than LED-FM +ve in 14 (21.52\%) patients based on CD4 count levels. More number of MTB was detected by both CBNAAT $28(43 \%)$ and LED-FM 10 (15.8\%) with the CD4 count of < 350 cells $/ \mu \mathrm{L}$. CBNAAT +ve vs. LED-FM +ve was $19(29.2 \%)$ vs. $6(9.23 \%)$ with CD4 count $100-350$ cells/ $\mu \mathrm{L}$ and $9(13.8 \%)$ vs. 4 $(6.15 \%)$ with CD4 count $<100$ cells/ $\mu \mathrm{L}$, which showed CBNAAT detect MTB better than LED-FM. 


\section{DISCUSSION}

In our study of the 80 PLWHA of ZN smear -ve suspected PTB, CBNAAT +ve in $49(61.25 \%)$ was more than LED-FM +ve in $17(21.25 \%)$, which was more than $2 \frac{1}{2}$ times.

In our study of the $40 \mathrm{HIV}+\mathrm{ve}$ vs. $40 \mathrm{HIV}$-ve ZN smear -ve suspected PTB, LED-FM was +ve in $8(20 \%)$ and CBNAAT was +ve in $21(52.5 \%)$ vs. LED-FM was +ve in $9(22.5 \%)$ and CBNAAT was +ve in 28 (70\%). CBNAAT is better than LEDFM for MTB detection in PLWHA. Both CBNAAT + ve and LED$\mathrm{FM}+\mathrm{ve}$ were higher in HIV -ve than HIV +ve.

In our study of the $40 \mathrm{HIV}$-ve patients, CBNAAT was +ve in $28(70 \%)$ and of the $40 \mathrm{HIV}+$ ve patients CBNAAT was +ve in $21(52.5 \%)$, which is similar to BD Taddese et al study ${ }^{8}$ i.e. of the 117 HIV -ve patients CBNAAT was +ve in 50 (42.73\%) and of the 55 HIV +ve patients CBNAAT was +ve in 24 (43.63\%) patients. Both studies showed AFB was more in HIV -ve than HIV +ve. Detection of AFB was decreased in PLWHA due to lower rates of caseous necrosis and sputum production. ${ }^{9}$

In our study CBNAAT was +ve in $49(61.25 \%)$ out of 80 PLWHA of ZN smear -ve suspected PTB, but in R Dewan et al study CBNAAT was +ve only in $40(40 \%)$ out of 100 PLWHA of sputum AFB +ve. In our study the sample size was less, but the AFB detection was high in $52.30 \%$ compared to their study of $61.25 \%$ vs. $40 \%$.

CBNAAT detected more MTB 22 (73.3\%) than LED-FM 13 (43.3\%) in suspected TB Lymphadenitis of 30 PLWHA, also CBNAAT positivity was more 5 (25\%) than LED-FM positivity $1(5 \%)$ of the 20 PLWHA of suspected TB pleural effusion.

In our study of the $49(61.3 \%)$ CBNAAT +ve PLWHA of ZN smear -ve suspected PTB, Rifampicin resistance was found only in $3(6.12 \%)$ patients compared to $6(1.44 \%)$ out of 416 patients in Gerado AU et al study ${ }^{10}$ and $3(15.78 \%)$ out of 19 HIV +ve TB - co-infection in Deepak A et al study. ${ }^{11}$

In our study of $65 \mathrm{HIV}+$ ve patients, CD4 count $<100$ cells $/ \mu \mathrm{L}$ in $14(21.5 \%)$ and with CD4 count $<350$ cells $/ \mu \mathrm{L}$ in $54(83 \%)$ patients which is similar to R Dewan et al study, 12 i.e. $32(32 \%)$ and $80(80 \%)$ patients respectively out of 100 patients.

In our study of the 65 HIV +ve patients, CBNAAT was +ve in $9(13.8 \%)$ with CD4 count $<100$ cells $/ \mu \mathrm{L}$ and in 28 $(43.07 \%)$ with CD4 count $<350$ cells $/ \mu \mathrm{L}$. In R Dewan et al study, 12 CBNAAT was +ve in 14 (14\%) patients with CD4 count $<100$ cells $/ \mu \mathrm{L}$ and 33 (33\%) with CD4 count $<350$ cells/ $\mu \mathrm{L}$ and in the same study CBNAAT was +ve in $14(14 \%)$ and $33(33 \%)$ respectively.

Increased number of MTB was detected by CBNAAT with decreased range of CD4 count. The range of MTB positivity was increased with the CD4 count $<350$ cells/ $\mu \mathrm{L}$ and range of MTB decreased with the CD4 count $>350$ cells $/ \mu \mathrm{L}$ by CBNAAT in both these studies. In our study, CBNAAT positivity was seen across all ranges of CD4 counts and no statistically significant difference was found between CBNAAT +ve and -ve patients, which was similar to R Dewan et al study. 12

\section{CONCLUSION}

In our study of the 130 PLWHA, CBNAAT +ve was higher than LED-FM +ve in the $80 \mathrm{ZN}$ smear -ve suspected PTB, 30 TB lymphadenitis and 20 TB pleural effusion samples i.e. 49 $(61.25 \%)>17$ (21.25\%), $20(66.66 \%)>12(40 \%), 5(25 \%)>$ $3(15 \%)$ respectively in the ratio of $2.88,1.66,1.66$ times in CBNAAT vs. LED-FM +ve. Of the 65 HIV +ve cases, CBNAAT was +ve in 34 (52.3\%) than LED-FM +ve in 14 (21.3\%) cases based on CD4 counts. Both CBNAAT +ve and LED-FM +ve were high with CD4 count $<350$ cells/mL, and less with CD4 count $>350$ cells $/ \mathrm{mL}$. Of the $49(61.3 \%)$ CBNAAT +ve ZN smear -ve suspected PTB of PLWHA Rifampicin Resistance was found only in $3(6.12 \%)$.

\section{REFERENCES}

[1] WHO. Fluorescent light-emitting diode (LED) microscopy for diagnosis of tuberculosis: policy statement. World Health Organization 2011.

[2] Boehme CC, Nabeta P, Hillemann D, et al. Rapid molecular detection of tuberculosis and rifampin resistance. N Engl J Med 2010;363(11):1005-15.

[3] Kasper DL, Fauci AS, Hauser S, et al. Harrison's Principles of Internal Medicine. Vol.1 \& Vol. 2. 19 th edn. McGraw-Hill Education 2015.

[4] Minion J, Sohn H, Pai M. Light-emitting diode technologies for TB diagnosis: what is on the market? Expert Rev Med Devices 2009;6(4):341-5.

[5] Josko D. Molecular bacteriology in the clinical laboratory. Clin Lab Sci 2010;23(4):237-41.

[6] Bodmer T, Ströhle A. Diagnosing pulmonary tuberculosis with the Xpert MTB/RIF test. J Vis Exp 2012;(62):e3547.

[7] WHO. Global tuberculosis report 2013. World Health Organization 2013.

[8] Taddese BD, Desalegn DM, Misganaw AS, et al. Comparison of GeneXpert against light-emitting diode fluorescent microscopy for the diagnosis of pulmonary tuberculosis in addis Ababa, Ethiopia. J Microb Biochem Technol 2018;10:1.

[9] Hopewell PC, Pai M, Maher D, et al. International standards for tuberculosis care. Lancet Infect Dis 2006;6(11):710-25.

[10] Gerardo AU, Azcona JM, Midde M, et al. Rapid Diagnosis of Pulmonary and Extrapulmonary Tuberculosis in HIV-Infected Patients. Comparison of LED Fluorescent Microscopy and the GeneXpert MTB/RIF Assay in a District Hospital in India. Tuberculosis Research and Treatment 2012;2012:1-4.

[11] Deepak A, Neerja J, Renu B, et al. Rapid detection of mycobacterium tuberculosis in sputum samples by Cepheid Xpert assay: a clinical study. Journal of Clinical and Research 2015;9(5):DC03-DC05.

[12] Dewan R, Anuradha S, Khanna A, et al. Role of CBNNAT for early diagnosis of PTB in HIV. J Indian Acad Clin Med 2015;16(2):114-7 